\title{
PISA 2012 Problem Çözme Yeterliğine Etki Eden Okul Değişkenlerinin İncelenmesi: Türkiye-Sırbistan Karşılaştırması
}

\section{PISA 2012 Analysis of School Variables Affecting Problem- Solving Competency: Turkey-Serbia Comparison}

\author{
Emine YAVUZ*
}

Bayram ÇETIN **

Öz

OECD’nin PISA 2012 Türkiye problem çözme raporuna göre Türkiye ve Sırbistan aynı matematik okuryazarlık düzeyindedir. Fakat Sırbistan'ın ortalama problem çözme yeterliğinin, Türkiye'den daha yüksek olduğu ifade edilmiştir. Bu doğrultuda bu çalışmada iki ülkenin problem çözme okuryazarlığına etki eden okul değişkenleri belirlenip karşılaştırılmıştır. Nedensel karşılaştırma yöntemi ile yürütülen bu çalışmada Türkiye örnekleminde 147 okuldan 4494 öğrenciye, Sırbistan örnekleminde ise 132 okuldan 4059 öğrenciye ait veri üzerinde ayrı ayrı HLM analizi yapılmıştır. HLM analizi sonucunda, Sırbistan için "engel ve aile bağışı” değişken etkileri, Türkiye için ise "terk, öğretmen morali ve matematik yarışı" değişken etkileri istatistiksel olarak anlamlı bulunmuştur. İki ülkede farklı değişkenlerin problem çözme okuryazarlığı üzerinde manidar etkileri olduğu görülse de bu değişkenlerin okul iklimi kavramının birer bileşeni olması oldukça dikkate değerdir.

Anahtar Kelimeler: PISA 2012, problem çözme yeterliği, Türkiye, Sırbistan.

\begin{abstract}
According to the OECD's PISA 2012 Turkey problem-solving report, Turkey and Serbia are at the same mathematical literacy level. However, Serbia's average of problem-solving competency is said to be higher than Turkey's. In this study, school variables that affect problem-solving competency of the two countries were examined and compared. The method of the study was causal comparison method, and HLM analysis was performed on data of 4494 students from 147 schools in Turkey sample and 4059 students from 132 schools in Serbia sample separately. As a result of HLM analysis, "obstacle and family donation" variable for Serbia and "abandon, teacher morale and mathematics competition" variable for Turkey were statistically significant. Although it was found that for each countries different variables influence the problem-solving competency, it was quite remarkable that these variables are in common in that they are components of the school climate concept.
\end{abstract}

Keywords: PISA 2012, problem solving competency, Turkey, Serbia.

\section{GíRiş}

Çok fazla değişkenin etkisinde sürekli değişen ve gelişen dünyada, toplumlar arası etkileşim kaçınılmaz hale gelmiştir. Bu durum, sınırların ortadan kalkmasına ve hiçbir toplumun ve ulusun, dış dünyadan bağımsız olarak kendi içerisinde kapalı kalamamasına neden olmuştur. Bu karmaşık ve rekabetin en üst düzeye çıktığı ortamlarda sağlanacak başarı, öncelikle nitelikli insan gücüne bağlıdır. $\mathrm{Bu}$ bağlamda eğitim, küresel dönemin dinamikleri doğrultusunda çok boyutlu ve çok yönlü nitelikli insan modelinin yetiştirilmesinde, en etkin ve önemli araçlardan biridir (Demir, 2010:1-5).

\footnotetext{
* Araştırma Görevlisi, Erciyes Üniversitesi, Eğitim Fakültesi, Kayseri-Türkiye, yavuzemine0@gmail.com, ORCID ID: https://orcid.org/0000-0002-1991-1416

** Doçent Doktor, Milli Eğitim Bakanlığı, Ölçme, Değerlendirme ve Sınav Hizmetleri Genel Müdürlüğü, Ankara-Türkiye, bcetin27@gmail.com, ORCID ID: https://orcid.org/0000-0001-5321-8028
}

Eğitimde ve Psikolojide Ölçme ve Değerlendirme Dergisi, Cilt 8, Sayı 4, Kış 2017, 435-452.

Journal of Measurement and Evaluation in Education and Psychology, Vol. 8, Issue 4, Winter 2017, 435-452. 
Ekonomik İşbirliği ve Kalkınma Örgütü (Organisation for Economic Cooperation and Development OECD) ülkelerin ihtiyaç duyduğu nitelikli insan gücü yetiştirme kapasitesini ortaya koymak ve bu kapasiteyi etkileyen değişkenleri belirlemek amacıyla, yetişmekte olan öğrencilerin başarılarının dikkate alındığı çalışmalar ve sınavlar yapmaktadır. Yapılan çalışmalar, projeye katılan ülkelerin genç nüfuslarını yetiştirmede karşılaştıkları sorunlara 1şı tutmakta ve küresel bazda problemleri olup olmadığına ilişkin bilgi vermektedir. Problemlerin varsa çözümünü araştırmak için başka araştırmalara ihtiyaç olduğunu ortaya koymaktadır. Var olan eğitim sistemlerinin mevcut durumunu tespit etmek, öğrencilerin bilgi toplumunun ihtiyaçlarına uygun yetişip yetişmediklerini anlamak, var olan eğitim sistemini geliştirmek ve diğer ülkelerin eğitim sistemleriyle karşılaştırma yapmak isteyen ülkeler de bu çalışmalara ve sınavlara katılmaktadırlar (Eğitimde Araştırma ve Geliştirme Daire Başkanlığı: EARGED, 2005). Eğitim sistemlerinin kalitesinin değerlendirilmesinde ve karşılaştırılabilirliklerini sağlayan bu uluslararası sınav, Uluslararası Öğrenci Başarısını Belirleme Programı'dır (The Program for International Student Assessment-PISA). PISA ilk defa 2000 yılında uygulanan, ülkelerdeki 15 yaşındaki öğrencilerin eğitimleri süresince, günlük hayatta karşılaşabilecekleri durumlar konusunda ne derece hazırlıklı yetiştirildiklerini belirlemek amacıyla geliştirilmiş bir programdır.

PISA ve Uluslararası Matematik ve Fen Eğilimi Çalışması (Trends in International Mathematics and Science Study - TIMSS) gibi karşılaştırmalı çalışmalar, özellikle vizyon geliştirme ve eğitimin planlanması süreçlerinde eğitimcilere ve politika üretenlere büyük katkı sağlamaktadır (Aydın, Sarıer ve Uysal, 2012: 22). Ayrıca öğrenci, okul ve eğitim sistemlerinin ortak bazı özelliklerini açıklamasıyla PISA; eğitimde kaliteyi, eşitliği ve verimliliği artırmak için kullanılabilecek yararlı bir araç olup öğrenci başarısında iyi bir kestiricidir (Schleicher, 2007). Bu tür çalışmalardan elde edilen verilerin analiz edilmesiyle ülkeler, mevcut eğitim sistemlerinin güçlü ve zayıf yönlerini, eğitim politikalarını, öğretim programlarını ve öğretmenlerin yeterliklerini gözden geçirilebilmektedir (Çelen, Çelik ve Seferoğlu, 2011:764-770).

PISA ile öğrencilerin sahip oldukları bilgi ve becerileri kullanabilme yeteneği, analiz edebilme, akıl yürütme ve okulda öğrenilen fen ve matematik kavramlarını kullanarak etkin bir iletişim kurma becerisine sahip olup olmamaları ölçülmeye çalışılmaktadır (OECD, 2009). Bu doğrultuda PISA'da ögrenciler, üç ana alan (okuma becerileri, fen ve matematik okuryazarlığı) ve yan alanlarda (problem çözme, vb.) değerlendirilmektedirler. Üç yılda bir yapılan bu araştırmaların her uygulamasında her konu alanıyla ilgili alt test bulunmakla birlikte, ağırlık verilen, daha detaylı incelenen alan değişmektedir. 2000 yılında başlayan bu uygulamalarda matematik ve problem çözme alanları ilk olarak 2003 y1lında ikinci olarak 2012 y1lında detaylı bir şekilde incelenmiştir (OECD, 2004b; 2013a).

PISA 2012'de problem çözme yeterliği, çözümü belli olmayan problem durumlarını öğrencinin önceden kazandığ 1 bilgi, beceri, yetenek ve psikolojik kaynaklar yardımıyla çözmesi olarak ifade edilmiştir (OECD, 2013a). Tanımdan anlaşılacağı üzere bu yeterlik sadece özel bir alana ait olan bilgileri öğrenmeyi değil, öğrencinin sahip olduğu ilgili bilgi ve becerilerini kullanabilmesini içermektedir. Nitekim sürekli değişen ve gelişen dünyada bireylerin başarılı olabilmeleri için değişime ayak uydurmaları, bu esnada önceden edinilmiş bilgi ve becerilerini kullanabilmeleri gerekmektedir. Bu bağlamda, bireylerin sürekli değişim içerisinde olan hayata aktif katılımlarında problem çözme yeterliği oldukça önemlidir (Yavuz ve Atar, 2016). Bu gibi nedenlerle problem çözme yeterliliğinin öğrencilere kazandırılması, birçok ülkenin eğitim programlarının temel amaçlarından biridir (Lesh ve Zawojewski, 2007).

OECD’nin PISA 2012 Türkiye problem çözme alanına ait rapora (OECD, 2013b) göre Türkiye ve Sırbistan aynı matematik okuryazarlık düzeyindedir. Fakat raporda Türkiye ve Sirbistan'ın aynı matematik okuryazarlık düzeyinde olmalarına rağmen Sırbistan'ın ortalama problem çözme yeterliğinin, Türkiye'den daha yüksek olduğu ifade edilmiştir. Türkiye ve Sirbistan PISA'ya ilk defa 2003 yılında katılmışlardır. Sırbistan eğitim sistemi incelendiğinde Türkiye ile pek çok benzerlik gösterdiği söylenebilir. Bu benzerlikleri açıklamak için Sırbistan eğitim sisteminden kısaca bahsetmek gerekir. Sırbistan'da eğitim 4 düzeyden meydana gelir: Okul öncesi, ilkokul, ortaöğretim ve yükseköğretim. Okul öncesi eğitime 7 yaşına kadar her öğrenci gidebilmektedir. İlkokul 7-14 yaş aralığını ve 8 sınıf düzeyini kapsar. Ayrıca her öğrenci için zorunludur. İlkokul iki kademeden oluşmaktadır. Birinci kademe 1-4. sınıfları, ikinci kademe ise 5-8. sınıfları içermektedir. Birinci 
kademeyi bitiren öğrenciler, ikinci kademeyi genellikle aynı okulda devam etmektedirler. Beşinci sınıfa başlayan öğrenciler tarih, geometri, biyoloji, fizik ve kimya gibi özel alan dersleri almaya başlarlar. Öğrenciler dersleri bir önceki sınıf düzeyinde olduğu gibi grup şeklinde alırlar fakat bazı derslere alan öğretmenleri girmektedir. Sekizinci sınıf sonunda öğrenciler okul ortalamaları ile birlikte ilkokul diploması alarak mezun olurlar (Baucal, Pavlovic-Babic ve Willms, 2007: 539). Sırbistan'da ortaöğretim 15-18 yaş aralığını kapsamaktadır. Ortaöğretimde üç tür lise bulunmaktadır: Genel lise, mesleki lise ve sanat okulları. Genel liseler sosyal ve fen bilimlerin okutulduğu dört yıllık liselerdir. $\mathrm{Bu}$ liselere giden öğrenciler üniversite için hazırlanırlar. Meslek liselerine giden öğrenciler üniversiteye hazırlanabilecekleri gibi genellikle 15 farklı alanda iş hayatına atılmak için hazırlanırlar. Bu liseler ilgili alana göre 1, 2, 3 veya 4 yıl sürebilir. Dört yıllık meslek lisesinden ve 2 y1l çalışmadan sonra bu öğrenciler bir yıl daha uzmanlık eğitimi alabilmektedirler. Sanat eğitimi okulları müzik, bale ve güzel sanatlar olarak dallara ayrılmıştır (Baucal ve Pavlovic-Babic, 2009; Teodorovic, 2005: 1216). Sırbistan'da öğrenciler meslek liselerine ilköğretim ikinci kademe ortalaması ile girebilirken genel liselere veya sanat okullarına yerleşebilmek için bir "giriş sınavına" girmeleri gerekmektedir. Bu sınav matematik ve dil testinden oluşmaktadır. Bu sınavın \%40'1 ve öğrencilerin ilkokul ikinci kademe ortalamalarının \%60'ı ile elde edilen ağırlıklı ortalama ile öğrenciler genel liselere veya sanat okullarına yerleşmektedir (Baucal ve diğerleri 2007: 540). Öğrencilerin ilgili sınıf düzeylerine devam etme yaşları dışında Türkiye ve Sırbistan eğitim sisteminin oldukça benzer olduğu görülmektedir. Sırbistan'da 15 yaş grubu öğrencileri lise düzeyinde öğrenimlerine devam ederken Türkiye'de 15 yaş grubu öğrencilerin bir kısmı ilköğretim son sınıf düzeyindedir (MEB, 2015).

PISA'da toplanan veri yapısı ve veri türüne bağlı olarak yapılan araştırmalar ile ülkeler belirlenen alanlarda birbirleriyle karşılaştırılabilmektedirler. İlgili literatür tarandığında Türkiye ve Sırbistan'ın herhangi bir y1la ait PISA problem çözme yeterliğini karşılaştıran bir çalışma bulunamazken, iki ülkenin PISA 2009 matematik başarısını karşılaştıran bir çalışma bulunmuştur. Kılıç, Çene ve Demir'in (2012) yaptığı bu çalışmada sekiz ülkedeki (Türkiye, Bulgaristan, Yunanistan, Azerbaycan, Rusya, İsrail, Sırbistan, Romanya ve Ürdün) öğrencilerin matematik başarısına etki eden ülke, okul ve öğrenci düzeyi değişkenleri ile öğrencilerin kullandıkları öğrenme stratejileri karşılaştırılmıştır. Yapılan üç düzeyli hiyerarşik lineer model analizi sonucunda cinsiyet, sosyo-ekonomik durum, ev eğitim kaynağı, kültürel aitlik, ezberleme, eleme ve kontrol stratejileri Sirbistan ile Türkiye'de istatistiksel olarak anlamlı etkiye sahip olduğu görülmüştür. Ayrıca öğrenci/öğretmen oranı değişkeni Türkiye'de istatistiksel olarak anlamlı etkiye sahiptir. Türkiye ve Sırbistan'ın eğitim sistemlerinin ve PISA matematik başarılarının paralellik göstermesi, öğrencilerin matematik başarılarına etki eden değişkenlerin benzerlik göstermesi beklentisini oluşturmaktadır. Nitekim Kılıç ve diğerlerinin (2012) yaptığı bu çalışma bu beklentiyi destekler niteliktedir.

Problem çözme yeterliliğinin öğrencilere kazındırılması konusu eğitim programlarına dahil edilmesi ile bu yeterliliğin kazandırılmasında okulların önemli işlevlerinin olması beklenir. Literatürde ülkeler arasında öğrenci başarısına etki eden okul değişkenlerinin karşılaştırıldığı çalışmalar mevcuttur. Örneğin İş (2003), farklı kültürlerde 15 yaşındaki öğrencilerin PISA 2000 matematik okuryazarlıklarına etki eden öğrenci, aile ve okul faktörlerini yapısal eşitlik modeli ile incelemiştir. Çalışması sonucunda okul kaynaklarından teknoloji kullanımı ve okul iklimi etkileri, Norveç’te anlamlı değilken, Japonya' da negatif yönde Brezilya' da ise pozitif yönde bir etkiye sahiptir. Ailenin okul ile ilişkisi ise öğrenci başarısı üzerinde her üç ülkede anlamlı etkiye sahiptir. Bu çalışmanın bulguları dikkate alındığında bir okul değişkeninin öğrenci başarısı üzerindeki etkisi farklı ülkelerde farklılaştığı görülmektedir. Satıcı da (2008), İş’in (2003) çalışmasına benzer şekilde yapısal eşitlik modeli ile ülkeleri karşılaştırmıştır. Satıcı (2008) çalışmasında Türkiye ve Hong Kong-Çin'de öğrencilerin PISA 2003 matematik başarılarını etkileyen öğrenci, öğretmen ve okul ile ilgili değişkenleri incelemiştir. Çalışması sonucunda Hong Kong-Çin'de öğrencilerin dersteki başarısı ile ilgili rekabetçi düşünceleri; Türkiye de ise okula ait olma örtük değişkeni öğrencilerin başarısına etki eden en önemli yordayıcılar olarak bulunmuş̧tur. En önemli yordayıcının Hong Kong-Çin'de öğrenci düzeyi değişkeni, Türkiye'de ise okul düzeyi değişkenin bulunması oldukça manidardır.

Fuller ve Clarke (1994), gelişmiş ülkelerdeki okul etkisi ile ilgili 100 çalışmayı incelemişlerdir. İncelemeleri sonucunda yönetici eğitim düzeyi veya çalışan değerlendirmesi 100 çalışmanın içinde 
etkili okul değişkenleri olarak üç ya da dört kez karşılaşılmıştır. Farrell ve Oliveira (1993) ise incelediği 50 çalışmanın içerisinde 7 analizden 4'ünde okul düzeyi değişkeni olan yönetici niteliğinin öğrenci başarısıyla anlamlı ilişkisi olduğunu gözlemlemiştir. Endüstrileşmiş ülkelerde öğrenci başarısını etkileyen okul değişkenlerinin belirlenmesi için yapılmış 100'den fazla çalışma üzerinde Bosker ve Witziers (aktaran Scheerens ve Bosker, 1997) bir meta-analiz yapmışlardır. Çalışmalarının sonucunda başarıdaki varyansın \%19'unun okul düzeyi tarafından açıklanabileceğini fakat bu oranın çalışmadan çalışmaya değişkenlik gösterdiğini belirlemişlerdir. Ryoo (2001), 35 ülkenin TIMSS 1995 verisini kullanarak öğrenci başarısına etki eden öğrenci, okul ve ülke düzeyi değişkenlerini incelemiştir. Araştırmasında HLM analizi kullanan Ryoo (2001), diğer çalışmalardan farklı olarak öğrenci başarısındaki varyansı üç parçaya ayırmıştır ve okul düzeyinin öğrenci başarısındaki varyansın \% 11.51'ini açıkladığını tespit etmiştir. Benzer şekilde uygulamaya katılan tüm ülkelerin TIMMS 2007 verisini kullandıkları çalışmalarında Mohammadpour ve Abdul Ghafar (2014), öğrenci başarısındaki varyansı üçe ayırmış ve bu oranı \%20.61 olarak tespit etmişlerdir. Bu oran OECD'nin (2004a) PISA 2003 verileri ile çoklu regresyon analizi kullanarak yaptığ çalışmasında yaklaşık \%28 olarak hesaplanmıştır. Ülkeler kendi verileri ile yaptıkları çalışmalarda ise bu oran değişmektedir. Ayrıca OECD'nin (2001) PISA 2000 çalışmasına katılan OECD ülkelerinin verileri ile yaptığ çalışmasında okul düzeyi değişkenlerinin (öğretmen morali, katılımı, okul anatomisi, seçiciliği ve öğretmen anatomisi) başarıda açıkladığı varyans yaklaşı \% \% 0.5-2 olarak hesaplanmıştır.

Yukarıda verilen farklı analizlerin kullanıldığı, başarıya etki eden okul düzeyi değişkenlerin incelendiği çalışmalar 1şığında okul düzeyinin başarıdaki varyansı açıklama oranlarının ülkeden ülkeye değiştiği söylenebilir. Bu bağlamda başarıyı etkileyen okul düzeyi değişkenlerin incelenmesi ülke başarıları arasındaki farklılıkları açıklamaya yardımcı olacaktır. Ayrıca OECD'nin PISA 2012 Türkiye problem çözme alanına ait rapora göre Türkiye ve Sırbistan aynı matematik okuryazarlık düzeyindedir (sırasıyla 408, 420). Fakat raporda Türkiye ve Sırbistan'ın aynı matematik okuryazarlık düzeyinde olmalarına rağmen Sırbistan'ın ortalama problem çözme yeterliği (473), Türkiye'den (454) daha yüksek olduğu ifade edilmiştir. Coğrafi konum olarak Türkiye'ye yakın, eğitim sistemi olarak Türkiye eğitim sistemine benzer bir sistemi olan bu ülkenin ortalama problem çözme yeterliğinin Türkiye'den yüksek olması düşündürücüdür. Bu doğrultuda Türkiye ve Sirbistan'ın ortalama problem çözme yeterliğine etki eden okul özelliklerinin belirlenmesi ve karşılaştırılması amaçlanmıştır.

\section{Araștırmanın Amacı}

Bu çalışmanın amacı Türkiye ve Sırbistan'ın ortalama problem çözme yeterliklerine etki eden okul değişkenlerini belirlemek ve karşılaştırmaktır. Bu amaçla aşağıdaki araştırma sorularına cevap aranmıştır.

Araştırma soruları:

1. Türkiye ve Sırbistan'da PISA 2012 çalışmasına katılan okulların problem çözme yeterliği puanları arasında fark var midır?

2. Türkiye ve Sırbistan'da PISA 2012 çalışmasına katılan okulların, eğer varsa, problem çözme yeterliği puanları arasındaki farkı açıklayan okul düzeyi değişkenleri nelerdir?

3. Türkiye ve Sırbistan'da etkisi manidar bulunan okul değişkenleri, PISA 2012 problem çözme yeterliği puanlarındaki varyansın ne kadarını açılamaktadır? Etkisi manidar bulunan okul değişkenleri her iki ülkede benzer midir?

Bu bölümde araştırmanın kapsamı ve yapılma gerekçesi kısaca açıklanmıştır. Çalışmanın amacıyla benzer amaçlar güden diğer çalışmalar literatür başlığı altında detaylı olarak incelenmiştir. Çalışmanın amacı ve literatür incelemesi doğrultusunda yöntem kısmına geçilmiş, çalışmanın örneklemi, ölçme araçları ve veri analizi yöntemi hakkında bilgiler verilmiştir. Veri analizi sonucunda elde edilen bulgular raporlandıktan sonra, bulgular tartışılmış ve sonuçlar özetlenmiştir. Çalışmanın son kısmında ise araştırma sonuçlarına dayalı önerilerde bulunulmuştur. 


\section{YÖNTEM}

Bu araştırmada Türkiye ve Sırbistan'ın 2012 yılı PISA sınavındaki problem çözme yeterliğine etki eden değiş̧kenlerin belirlenmesi ve karşılaştırılması amaçlandığından nicel araştırma yöntemlerinden nedensel karşılaştırma deseni kullanılmıştır. Nedensel karşılaştırma araştırmaları, ortaya çıkmış/var olan durumun veya gruplar arasındaki farklılıkların nedenlerini, bu nedenleri etkileyen değişkenleri ya da etkinin sonuçlarını koşullar ve katılımcılar üzerinde herhangi bir müdahale olmaksızın belirlemeyi amaçlayan çalışmalardır (Büyüköztürk, Çakmak, Akgün, Karadeniz, ve Demirel, 2008).

\section{Örneklem}

Ülkeler PISA uygulamalarını kendi olanakları ile PISA Yönetim Kurulu tarafından belirlenen PISA Teknik Standartlarına uygun bir şekilde yaparlar. Uygulama sonucunda elde edilen verilerin güvenirlikleri ise ilgili yılın PISA teknik raporunda raporlanmaktadır. Çalışmaya katılan ülkelerde iki basamaklı tabakalamalı örnekleme yöntemi kullanılır. İlk olarak her ülke için 15 yaş öğrencilerin bulunduğu okullar oluşturulan listelerden sistematik seçilerek, seçilen her okuldan eşit olasılıkla rastgele olarak 35 öğrenci belirlenir. Türkiye'de PISA 2012'ye, 170 okuldan 4848 öğrenci katılırken; Sırbistan'da 142 okuldan 4353 öğrenci katılmıştır.

\section{Veri Toplama Araçları}

\section{Problem çözme alanina ait alt test}

Problem çözme yeterliğini ölçmek için geliştirilen ölçme aracı maddelerin hazırlanmasından puanlanmasına kadar geçen süreçte bir dizi uygulamadan geçmiştir. Bu bölümde bu aşamalar kısaca özetlenmiştir. Daha önceki dört PISA değerlendirmesinde kazanılan tecrübeler, mümkün olan en yüksek seviyedeki kültürlerarası ve uluslar arası çeşitliliğe sahip kavramsal olarak titiz materyallere ulaşılmasına yardımcı olmak için çeşitli test merkezlerinin geliştirme uzmanlığını kullanmanın önemini göstermiştir. Bu nedenle PISA 2012 yeni problem çözme maddelerinin hazırlanması için ACER, kültürel olarak farklı ve tanınmış kurumlardan dokuz test geliştirme merkezi ile anlaşmıştır. Süreçte ACER bu merkezler arasında materyallerin dağıtımını koordine etmiş ve her bir merkezdeki madde yazarlarının katıldığı kooperatif geliştirme süreçlerini yönetmiştir. Yeni geliştirilen problem çözme maddelerinin değerlendirmesi için PISA Uluslararası Konsorsiyumu ve ulusal başvurular sonucu kabul edilen uzmanlardan bir uzman grubu oluşturulmuştur. Uzmanı Grubu, test geliştirme merkezlerinin ilk geliştirme çalışmalarından sonra, problemleri çözme yetkinlikleri ile ilgili tüm materyalleri gözden geçirmiştir. Bunun için küçük ölçekli bilişsel laboratuvar etkinlikleri yapılmış ve bunlar Ulusal Merkezler tarafından incelenmiş, saha testi yapılmıştır. Daha sonra test geliştirmenin ikinci aşamasında her bir uzman grubun, ilk geliştirme aşamasından sorumlu olmadığı en az bir testi gözden geçirmiştir. Madde hazırlama sürecine yönelik bir rehber hazırlanmış ve bu konu üzerine çalıştay düzenlenmiştir. Uluslararası ve ulusal gözden geçirmeler sonucunda maddeler, alan uygulamasına tabi tutulmuşlardır. Problem çözme yeterliğini ölçmek için geliştirilen araçta toplamda 42 madde bulunmaktadır. Bu maddeler, ana uygulamadan bir y1l önce, 2011 y1lında tüm katılımc1 ülkelerde yapılan alan uygulamasında test edilen, yeni geliştirilen 79 adet problem çözme maddesinin oluşturduğu bir havuzundan seçilmiştir. Tüm soruların yanıtlanması için geçen süre 80 dakikadır. Ana uygulamada problem çözme soruları, her birinin cevaplanma süresi yaklaşık 20 dakika olacak şekilde 4 gruba ayrılmıştır. Bu dört gruptan farklı ikili kombinasyonlar ile formlar oluşturulmuştur. Uygulamada her bir öğrencinin bir formu yaklaşık 40dakikada cevaplaması gerekmiştir. Uygulamaya katılan ülkeler veri kümesinin güvenilirliği ve ölçme hatası ağırlıklandırılmış olabilirlik kestirimi yöntemi ile sırasıyla 0.79 ve 1.27 olarak kestirilmiştir. Ağırlıklandırılmış olabilirlik kestirimi yöntemi, iç tutarlılığın madde tepki kuramına (MTK) dayalı olarak kestirilmesi şeklinde ifade edilebilir. Ayrıca problem çözme alanının güvenirliği Türkiye için 0.86, Sırbistan için 0.85 olarak PISA 2012 teknik raporunda yayınlanmıştır (OECD, 2014: 32-230). 
PISA 2012'de öğrencilerin problem çözme yeterliklerinin değerlendirilmesinde üç alan belirlenmiştir: Problem içeriği/bağlamı, problem durumunun doğası ve problemin çözümündeki bilişsel süreç (OECD, 2013a). Bu çalışmada problem çözme yeterliği puanlarına etki eden değişkenler incelendiği için öğrencilere ait toplam puanlar üzerinden işlem yapılmıştır. Bu nedenle öğrencilerin PISA 2012'de problem çözme yeterliklerinin değerlendirildiği üç alan hakkında detaylı bilgi verilmemiştir.

PISA'da 2003'ten 2012'ye kadar geçen süreçte problem çözmenin değerlendirme çerçevesi çeşitli konularda (kompleks problem çözümü, bilgi aktarımı, bilgisayar destekli problem çözümü gibi) genişletilmiştir. PISA 2012'de bireysel problem çözme kapasitelerin belirlenmesi üzerinde yoğunlaşılmıştır. 2003 yılında kağıt-kalem sınavı olarak uygulanan problem çözme alanına ait alt testi, 2012 yılında bilgisayar destekli olarak uygulanmaya başlanmıştır (OECD, 2013a).

\section{Okul anketi}

Bu çalışmada yer alan tüm değişkenler, PISA uygulamalarına katılan öğrencilerin okullarıyla ilişkili verilerin elde edilmesi için OECD tarafından oluşturulan okul anketinden elde edilmiştir. Cevaplaması yaklaşık 30 dakika alan bu anket okul yöneticileri tarafından doldurulmaktadır. Anket 8 bölümden oluşmaktadır. Bu bölümler (OECD, 2013a): 1) Okulun yapısı ve organizasyonu, 2) Öğrenci ve ögretmen yapısı, 3) Okul kaynakları, 4) Okulun eğitimi, müfredatı ve değerlendirmesi, 5) Okul iklimi, 6) Okul politikaları ve uygulamaları, 7) Okuldaki finansal eğitim ve 8) Online okul anketi için ek sorudur.

\section{Verilerin Analizi}

Çalışmanın başında PISA 2012 okul anketinde bulunan tüm değişkenlerin problem çözme yeterliği puanına etkilerinin incelenmesi düşünülmüştür. İki ülkeye ait okul değişkenleri aşağıdaki işlemler uygulanarak çalışma amacına uygun şekilde düzenlendikten sonra HLM analizine dahil edilmiştir.

1. Finansal okuryazarlık uygulamasına Türkiye ve Sırbistan katılmadığı için okuldaki finansal eğitim ile ilgili maddeler veriden silinmiştir.

2. Endeks puanı olan değişkenlerin (matematik sınıfı için yetenek grupları, eğitimsel liderlik, öğretmen morali, sorumluluk, vb.) maddeleri (gözlenen değişkenleri) veriden silinmiştir.

3. Çok kategorili değişkenlerin kategori sayısı ikiye indirilmiştir.

4. Bağımlı değişken ile bağımsız değişkenler arasındaki korelasyon incelenmiş ve bağımlı değişken ile ilişkisi olmayan okul değişkenleri veri setinden silinmiştir. Son durumda veri setinde problem çözme yeterliği puanı ile ilişkili Sırbistan verisinde 21 değişken; Türkiye veri setinde ise 47 değişken kalmıştır.

5. Yapılan inceleme sonucunda bu değişkenlerden 12 'sinin her iki ülke için ortak olduğu görülmüştür.

6. Kayıp veriler incelenmiştir. Öncelikli olarak kayıp verilerin sistematik olarak dağılıp dağılmadığı kontrol edilmiştir. SPSS programında yapılan kayıp veri analizi ile Little'ın MCAR testi manidar bulunmamıştır. Bu değerin manidar bulunmaması verilerin sistematik olarak dağılmadığını göstermektedir. Kayıp verilerde herhangi bir sistematik dağılım olmadığı görüldügü ve kategorik veriler için de kayıp veri ataması yapılması gerektiği için SPSS'te çoklu atama (multiple imputation-MI) yapılmıştır.

7. Veride bazı okullarla ilgili çok az bilgi olduğu başka bir ifade ile bu okul müdürlerinin anketteki maddelerin birçoğunu cevaplamadıkları görülmüştür. Bu okullar ve 5'den az öğrenciye sahip okullar analiz dışı bırakılmıştır. Buna paralel olarak ilgili okullardaki öğrencilere ait bilgiler de veriden temizlenmiştir.

8. Uç değer ve çoklu bağlantılılık kontrol edilmiştir ve çoklu bağlantı olmadığ1 görülmüştür. Mahanalobis uzaklığına göre uç değerler serbestlik derecesi değişken sayısına (12) eşit olmak 
üzere, söz konusu serbestlik derecesi için elde edilen ki-kare, üst sınır olarak kabul edilir. Veri setinde bu sınırın üzerindeki değerler uç değer olarak kabul edilmiştir. Türkiye'de 10 okul; Surbistan'da 9 okul uç değer olarak belirlenmiştir.

Tablo1. HLM Analizine Dahil Edilen Değişkenlere Ait Betimsel İstatistikler

\begin{tabular}{|c|c|c|c|c|c|c|c|}
\hline Analiz Düzeyi & Ülkeler & Değişkenler & $\mathrm{N}$ & Ortalama & SD & Minimum & Maksimum \\
\hline \multirow{10}{*}{ Düzey-1 } & \multirow{5}{*}{ Türkiye } & PV1 & 4494 & 454.07 & 78.63 & 220.55 & 712.40 \\
\hline & & PV2 & 4494 & 454.22 & 79.17 & 171.85 & 732.69 \\
\hline & & PV3 & 4494 & 453.84 & 78.27 & 167.79 & 718.89 \\
\hline & & PV4 & 4494 & 453.84 & 78.70 & 196.20 & 713.21 \\
\hline & & PV5 & 4494 & 454.35 & 79.20 & 235.16 & 721.33 \\
\hline & \multirow{5}{*}{ Sirbistan } & PV1 & 4059 & 470.67 & 87.79 & 141.01 & 770.83 \\
\hline & & PV2 & 4059 & 471.74 & 89.47 & 145.06 & 742.43 \\
\hline & & PV3 & 4059 & 471.11 & 87.47 & 127.21 & 757.85 \\
\hline & & PV4 & 4059 & 471.27 & 87.58 & 156.43 & 739.99 \\
\hline & & PV5 & 4059 & 470.32 & 89.27 & 116.66 & 743.24 \\
\hline \multirow{24}{*}{ Düzey-2 } & \multirow{12}{*}{ Türkiye } & Engel & 147 & 0.05 & 1.03 & -1.67 & 3.57 \\
\hline & & Nmo & 147 & 4.98 & 3.43 & 0.00 & 18.00 \\
\hline & & Terk & 147 & 3.96 & 5.93 & -9.52 & 30.00 \\
\hline & & Bagis & 147 & 8.48 & 13.04 & 0.00 & 60.00 \\
\hline & & Uzmanlık & 147 & 18.24 & 35.04 & 0.00 & 100.00 \\
\hline & & OranMo & 147 & 0.12 & 0.05 & 0.00 & 0.23 \\
\hline & & OgrtMorali & 147 & -0.24 & 1.04 & -2.47 & 1.45 \\
\hline & & Eksiklik & 147 & 0.89 & 1.00 & -1.09 & 3.60 \\
\hline & & MatematikYarisi & 147 & 1.82 & 0.39 & 1.00 & 2.00 \\
\hline & & SanatKulubu & 147 & 1.51 & 0.50 & 1.00 & 2.00 \\
\hline & & Aktivite & 147 & 1.55 & 0.50 & 1.00 & 2.00 \\
\hline & & EkstraAktivite & 147 & 1.70 & 1.07 & 0.00 & 3.00 \\
\hline & \multirow{12}{*}{ Sirbistan } & Engel & 132 & -0.21 & 0.92 & -2.37 & 2.60 \\
\hline & & Nmo & 132 & 4.54 & 2.49 & 0.00 & 15.00 \\
\hline & & Terk & 132 & 1.70 & 2.27 & -2.46 & 10.00 \\
\hline & & Bagis & 132 & 18.30 & 28.71 & -12.98 & 100.00 \\
\hline & & Uzmanlık & 132 & 47.63 & 42.33 & -37.41 & 110.51 \\
\hline & & OranMo & 132 & 0.08 & 0.03 & 0.00 & 0.17 \\
\hline & & OgrtMorali & 132 & -0.35 & 0.85 & -2.15 & 1.45 \\
\hline & & Eksiklik & 132 & -0.77 & 0.60 & -1.77 & 1.19 \\
\hline & & MatematikYarisi & 132 & 1.28 & 0.45 & 1.00 & 2.00 \\
\hline & & SanatKulubu & 132 & 1.51 & 0.50 & 1.00 & 2.00 \\
\hline & & Aktivite & 132 & 1.13 & 0.34 & 1.00 & 2.00 \\
\hline & & EkstraAktivite & 132 & 2.04 & 0.92 & 0.00 & 3.00 \\
\hline
\end{tabular}

9. Son durumda HLM analizinde öncelikle varsayımlar kontrol edilmiştir. Bunun için HLM programının yardımı ile düzey 1 ve düzey 2 için artık dosyaları oluşturulmuştur. $\mathrm{Bu}$ dosyalardaki verilerin kullanılmasıyla artıkların normal dağılımı, homojenlikleri ve birbirleriyle olan ilişkileri incelenmiştir. İncelemeler sonucunda varsayımların sağlandığı yani, artıkların normale yakın, homojen bir şekilde dağıldıkları ve birbirleriyle ilişkisiz oldukları görülmüsstür. Varsayımların sağlandığı görüldükten sonra araştırma problemlerinin cevaplanması ile ilgili modeller analiz edilmiştir.

10. Son olarak 12 değişkenden hangilerinin analize dahil edilmesi gerektiğini belirlemek için açımlayıcı analiz yapılmıştır. Açımlayıcı analiz HLM programının seçeneklerinden biri olup, modele hangi değişkenlerin dahil edilmesinin uygun olduğuna karar vermek için kullanılan 
bir özelliktir. Bu analizde değişkenlerin $\mathrm{t}$ değerleri hesaplanmış ve 12 değişkenin de $\mathrm{t}$ değeri manidar bulunmuş. $T$ değeri manidar bulunan tüm değişkenler modele dahil edilmiştir.

İncelemeler sonucunda Türkiye örnekleminde 147 okuldan 4494 öğrenci, Strbistan örnekleminde ise 132 okuldan 4059 öğrenci ait veri kalmıştır. PISA'da her bir öğrencinin problem çözme yeterliği puanı için beş olası değer (plausible value, PV1-5) raporlanmaktadır. Bu değerler OECD tarafından öğrenci başarılarının farklı ağırlıklandırma yöntemleriyle hesaplanmış halidir. HLM7.01 programı her bir öğrenciye ait beş puanı aynı anda analize dahil ederek tek bir bağımlı değişken gibi model testini gerçekleştirmektedir. Bu nedenle öğrencilerin problem çözme yeterliği puanlarına ait beş olası değere herhangi bir işlem yapılmadan, doğrudan HLM analizine dahil edilmiştir.

HLM analizinde 1. düzeyi öğrenci değişkenleri, 2. düzeyi ise okul değişkenleri oluşturmaktadır. "Matematik yarışmaları, sanat kulübü ve matematikle ilgili ülkeye özgü aktiviteler" değişkenleri kategorik olarak (evet=1, hayır=2), diğer değişkenler ise sürekli değişken olarak analize dahil edilmiştir. HLM analizine dahil edilen değişkenlere ait betimsel istatistiklere Tablo 1'de yer verilmiştir. Tablo 1'de "Engel” değişkeni, öğrencilerin öğrenmelerini engelleyici özelliklerini; "NMO" değişkeni örneklemdeki okullarda görev yapmakta olan toplam matematik öğretmeni sayısını; "Terk" değişkeni öğrencilerin gittikleri okuldaki yıllık ortalama okulu bırakan öğrenci sayısını, "Bagıs" değişkeni velilerin okulu destekleme miktarını, "Uzmanlık" değişkeni öğretmenlerin uzmanlıklarını, tecrübelerini; "OranMo" değişkeni bir okuldaki matematik öğretmeni sayısının toplam öğretmen sayısına oranını; "OgrtMorali" değişkeni öğretmenlerin moralini; "Eksiklik" değişkeni okuldaki öğretmen eksikliğini; "MatematikYarisi" değişkeni okullarda düzenlenen matematik yarışmalarını; "Aktivite" değişkeni ülkeye özgü matematiksel etkinlikleri; "EkstraAktivite” değişkeni ise her ülkenin matematik ile ilgili yaptığı ekstra aktiviteleri ifade etmektedir. Ayrıca veri analizinde bazı değişkenlerin indeks puanı kullanıldığı için betimsel istatistiklerinde farklı minimum ve maksimum değerlere sahip oldukları görülmektedir.

\section{HLM analizi}

Sosyal bilimlerde veri analizi için, kullanılan analiz yöntemine bağlı olarak veriler bir üst düzeyde toplanabilmekte (aggregation) veya üst düzeye ait veriler alt düzeye yayılabilmektedir (disaggregation). Verilerin tek bir düzeye toplanmasının bir amacı, tek düzeyli analiz yöntemlerinin verilerin analizinde kullanabilmelerini sağlamaktır. Tek düzeyli analiz yöntemleri gözlemlerin bağımsızlığı ve varyansların homojenliği sayıltılarının sağlanmasını gerektirmektedirler. Geniş örneklemlerden elde edilen veriler bu sayıltıların sağlanmasını yapıları gereği zorlaştırmaktadırlar. Aynı okula giden öğrencilerin birbirlerine ilgili değişken konusunda farklı okula giden öğrencilerden daha çok benzemeleri gözlemlerin bağımsızlığ 1 varsayımının ihlaline işaret eder ve bu duruma örnek verilebilir (Raudenbush ve Bryk, 2002). Ayrıca geniş örneklemlerde belirlenen özellik bakımından bir okul homojenken diğer okul heterojen olabilmektedir. Böyle bir durumda ise varyansların homojenliği sayıltısı ihlal edilmiş olur (Hox, 2010, s.4-7). Bu varsayımların ihlali sonucunda tek düzeyli analiz yöntemleri yanlı kestirimler yapabilmektedir (Bryk ve Raudenbush, 1988). Bu nedenle geniş örneklemli çalışmalarda tek düzeyli analiz yöntemlerinin olası yanlı sonuçlarından kaçınmak için çok düzeyli analiz yöntemlerinin kullanılması önerilmektedir (Raudenbush ve Bryk, 2002, s. 3-6). Bu çalışmada verilerin analizi için çok düzeyli analiz yöntemlerinden hiyerarşik lineer modeller (HLM) kullanılmıştır. HLM analizinde kullanılan algoritma standart hataları düzelterek (adjust) sonuçların yanlılığını ortadan kaldırır. Bu nedenle HLM analizinde tek düzeyli analizler (OLS, doğrusal regresyon, vb.) gibi katsayı tahminlerine ait standart hata değerleri olduğundan daha düşük kestirilmez. Ayrıca HLM'de bireysel etkiler incelenebildiği gibi grup etkileri de incelenebilmektedir ve farklı düzeyler arasındaki hipotezler eş zamanlı test edilebilmektedir (Cadiz, 2001; Raudenbush ve Bryk, 2002, s. 38).

$\mathrm{Bu}$ araştırmada, araştırma problemlerinin cevaplanması için HLM7.01 programı kullanılmıştır. Aşağıda bu araştırma kapsamında test edilen HLM modellerine yer verilmiştir.

1) Tek-yönlü varyans analizi rastgele etkiler modeli: Bu model "PISA 2012 çalışmasına katılan okulların problem çözme yeterliği puanları arasında fark var mıdır?" sorusunu cevaplamak için 
kurulmuştur. Literatürde "boş model" olarak da bilinen bu model ile ilk araştırma problemi cevaplanırken eş zamanlı olarak veri analizinde HLM kullanımının uygun olup olmadığ incelenir. Model eşitlikleri aşağıdaki gibidir:

Düzey 1: $\mathrm{Y}_{\mathrm{ij}}=\beta_{0 \mathrm{j}}+\mathrm{r}_{\mathrm{ij}} \quad$ Düzey 2: $\beta_{0 \mathrm{j}}=\gamma_{00}+\mathrm{u}_{0 \mathrm{j}}$

Burada,

$\mathrm{Y}_{\mathrm{ij}}$ : Her bir öğrencinin problem çözme yeterliği puanını,

$\beta_{0 \mathrm{j}}: \mathrm{j}$. okulun problem çözme yeterliği puan ortalamasını,

$\mathrm{r}_{\mathrm{ij}}$ : j. okuldaki i. öğrencinin hata puanını, yani i. öğrencinin $\mathrm{j}$ okulunun ortalama problem çözme yeterliği puanından farkıdır. "0" ortalama ve $\sigma^{2}$ varyansı ile normal dağılım gösterdiği varsayılır.

$\gamma_{00}$ : Tüm öğrencilerin problem çözme yeterliği puan ortalamalarını,

$\mathrm{u}_{0 \mathrm{j}}$ : j. okuldaki hata puanını göstermektedir, yani j okulunun genel başarı ortalamasından farkıdır. "0" ortalama ve $\tau_{00}$ varyansı ile normal dağılım gösterdiği varsayılır.

2) Ortalamaların bağımlı olduğu model: İkinci araştırma probleminin cevaplanması için kurulan bu modelde ikinci düzeye problem çözme yeterliği ile ilişkili okul değişkenleri atanarak HLM analizi yapılır. Analiz sonucuna bağlı olarak hangi okul değişkenlerinin problem çözme yeterliğine etki ettiği belirlenir.

Düzey 1: $\mathrm{Y}_{\mathrm{ij}}=\beta_{0 \mathrm{j}}+\mathrm{r}_{\mathrm{ij}}$

Düzey 2:

$\beta_{0 j}=\gamma_{00}+\gamma_{01}($ Engel $)+\gamma_{02}(\mathrm{Nmo})+\gamma_{03}($ Terk $)+\gamma_{04}($ Bagis $)+\gamma_{05}($ Uzmanlik $)+\gamma_{06}($ OranMo $)+\gamma_{07}($ OgrtMrrali $)+$ $\gamma_{08}($ Eksiklik $)+\gamma_{09}$ (MatematikYarisi) $+\gamma_{10}$ (SanatKulubu $)+\gamma_{11}($ Aktivite $)+\gamma_{12}($ EkstraAktivite $)+u_{0 j}$

Bu model için birinci modelden farklı olarak $\gamma_{0 \mathrm{k}}$ sembolü tanımlanabilir.

$\gamma_{0 k}$ : Okul düzeyi bağımsız değişkenlerindeki $(\mathrm{k}=1,2,3,4)$ bir birim değişikliğin okul ortalama problem çözme yeterliği puanlarında meydana getirdiği değişiklik olarak yorumlanır.

\section{BULGULAR}

Bu bölümle araştırma problemleri ile ilgili bulgulara yer verilmiştir.

\section{Araştırma Problemi ile İlgili Bulgular}

PISA 2012 çalışmasına katılan okulların problem çözme yeterliği puanları arasında bir farkın olup olmadığının belirlenmesi için oluşturulan tek-yönlü varyans analizi rastgele etkiler modeli analiz sonuçları Tablo 2a ve Tablo 2b'de verilmiştir.

Tablo 2a. Tek-Yönlü Varyans Analizi Sabit Etkiler Modeli Analiz Sonuçları

\begin{tabular}{|c|c|c|c|c|c|}
\hline Ülkeler & Sabit etkiler & Katsayılar & Standart hata(SH) & $T$ & Yaklaşık s.d. \\
\hline Türkiye & Kesim noktas1, $\gamma_{00}$ & $449.43 *$ & 4.85 & 92.73 & 146 \\
\hline Sırbistan & Kesim noktas $1, \gamma_{00}$ & $468.71 *$ & 5.05 & 92.86 & 131 \\
\hline
\end{tabular}

${ }^{*} p<0.05$

Tablo 2a incelendiğinde PISA 2012 problem çözme yeterliği için genel ortalama Türkiye için 4.85 standart hata ile 449.43 olarak; Sırbistan için 5.05 standart hata ile 468.71 olarak kestirilmiştir. Kestirilen genel ortalamalar için güven aralığı hesaplandığında $\left(\% 95 \mathrm{CI}\left(\gamma_{00}\right)=\gamma_{00} \pm(1.96)(\mathrm{SH})\right)$ 
Türkiye'nin genel ortalamasının gerçek değerinin 439.92-458.94 puanları arasında; Sırbistan'ın genel ortalamasının gerçek değerinin ise 458.81-478.61 puanları arasında olması beklenir. Ayrıca analiz sonucunda Türkiye genel ortalamasının güvenirlik katsayısı 0.97 olarak, Sırbistan'ın ise 0.94 olarak bulunmuştur.

Tablo 2b. Tek-Yönlü Varyans Analizi Rastgele Etkiler Modeli Analiz Sonuçları

\begin{tabular}{llllll}
\hline & Rastgele Etkiler & $\begin{array}{c}\text { Standart } \\
\text { Sapma }\end{array}$ & Varyans bileşenleri & s.d. & $\chi^{2}$ \\
\hline \multirow{2}{*}{ Türkiye } & Düzey-2, $\left(\mathrm{u}_{0}\right)$ & $57.76^{*}$ & 3335.68 & 146 & 5047.44 \\
& Düzey-1, $\left(\mathrm{r}_{\mathrm{ij}}\right)$ & 54.59 & 2980.00 & & \\
\hline \multirow{2}{*}{ Sirbistan } & Düzey-2, (u0) & $55.74^{*}$ & 3107.07 & 131 & 2533.34 \\
& Düzey-1, $\left(\mathrm{r}_{\mathrm{ij}}\right)$ & 70.04 & 4904.92 & & \\
\hline$* p<0.05$ & & & & &
\end{tabular}

Tablo 2b'de Türkiye için ortalama problem çözme yeterliği puanının okullar içi değişkenliğin $\left(\sigma^{2}\right)$ 2980.00 olarak ve okullar arası değişkenliğin $\left(\tau_{00}\right) 3335.68$ olarak kestirildiği görülmektedir $\left(\chi^{2}=5047.44, \mathrm{sd}=146\right)$. Sırbistan için ortalama problem çözme yeterliği puanının okullar içi değişkenliğin $\left(\sigma^{2}\right) 4904.92$ olarak ve okullar arası değişkenliğin $\left(\tau_{00}\right)$ 3107.07olarak kestirildiği görülmektedir $\left(\chi^{2}=2533.34, \mathrm{sd}=131\right)$. Her iki ülke için $\left(u_{00}\right)$ katsayısının istatistiksel olarak anlamlılığ incelendiğinde bu katsayıya ait $p$ değerinin anlamlı olduğu $(p<0.05)$ görülmüsştür. Bu katsayının anlamlı olması her iki ülkede problem çözme yeterliğinin okuldan okula değiştiğini göstermektedir. Başka bir ifade ile PISA 2012 çalışmasına katılan okulların ortalama problem çözme yeterliği puanları arasında fark vardır. Bu doğrultuda verinin yuvalanmış bir yapı gösterdiği, bunun için verinin çok düzeyli modeller ile analiz edilmesi gerektiği belirlenmiştir.

Problem çözme yeterliği puanlarındaki değişkenliğin düzeyler tarafından ne kadar açıklandığı sınıflar arası korelasyon (ICC) yardımıyla hesaplanır (Raudenbush ve Bryk, 2002).

Türkiye için:

Okullar içi açıklanan varyans oranı: $\hat{p}=2980.00 /(3335.68+2980.00)=0.47$

Okullar arası açıklanan varyans oranı: $\hat{p}=3335.68 /(3335.68+2980.00)=0.53$

Surbistan için:

Okullar içi açıklanan varyans oranı: $\hat{p}=4904.92 /(3107.07+4904.92)=0.61$

Okullar arası açıklanan varyans oranı: $\hat{p}=3107.07 /(3107.07+4904.92)=0.39$

Sınıflar arası korelasyonun hesaplanması sonucunda problem çözme yeterliği puanlarındaki değişkenliğin okul düzeyi tarafından açıklanma oranı Türkiye için yaklaşık 0.53 iken Sırbistan için yaklaşık 0.39 'dur.

\section{Araştırma Problemi ile İlgili Bulgular}

PISA 2012 çalışmasına katılan okulların, eğer varsa, problem çözme yeterliği puanları arasındaki farkı açıklayan okul düzeyi değişkenlerinin belirlenmesi için ortalamaların bağımlı olduğu model kurulmuş, modelin analiz sonuçları Türkiye için Tablo 3'te, Surbistan için Tablo 4'te verilmiştir. Tablo 3 incelendiğinde öğrencilerin problem çözme yeterliği puanlarına 3 değişken etkisinin (terk, öğretmen morali ve matematik yarışı) manidar $(p<0.05)$; 9 (engel, toplam matematik öğretmeni sayısı, bağış, uzmanlık, matematik öğretmeni oranı, eksiklik, sanat kulübü, aktiviteler ve ekstra aktiviteler) değişken etkisinin ise manidar olmadığ $1(p>0.05)$ görülmektedir. 
Yavuz, E., Çetin, B. / PISA 2012 Problem Çözme Yeterliğine Etki Eden Okul Değişkenlerinin İncelenmesi: TürkiyeSırbistan Karşılaştırması

Tablo 3. Türkiye için Ortalamaların Bağımlı Olduğu Modeli Sabit Etkiler Analizi Sonucu

\begin{tabular}{llllll}
\hline Sabit etkiler & Katsayılar & $\begin{array}{l}\text { Standart } \\
\text { hata }\end{array}$ & $t$ & Yaklaşık s.d & $\begin{array}{l}\text { Etki } \\
\text { Büyük. }\end{array}$ \\
\hline Kesim Noktas1, $\beta_{00}$ & 501.14 & 36.97 & 13.56 & 134 & \\
Engel, $\beta_{01}$ & 1.17 & 4.07 & 0.29 & 134 & --- \\
Nmo, $\beta_{02}$ & 2.82 & 1.54 & 1.835 & 134 & -- \\
Terk, $\beta_{03}$ & $-1.32^{*}$ & 0.64 & -2.06 & 134 & -0.02 \\
Bag1s, $\beta_{04}$ & 0.18 & 0.25 & 0.70 & 134 & --- \\
Uzmanlik, $\beta_{05}$ & 0.16 & 0.13 & 1.23 & 134 & --- \\
OranMo, $\beta_{06}$ & 72.95 & 82.24 & 0.89 & 134 & -- \\
OgrtMorali, $\beta_{07}$ & $10.56^{*}$ & 4.65 & 2.27 & 134 & 0.18 \\
Eksiklik, $\beta_{08}$ & 1.44 & 3.93 & 0.37 & 134 & --- \\
MatematikYarisi, $\beta_{09}$ & $-48.65^{*}$ & 14.21 & -3.42 & 134 & -0.84 \\
SanatKulubu, $\beta_{10}$ & 6.39 & 12.74 & 0.50 & 134 & --- \\
Aktiviteler, $\beta_{11}$ & 12.67 & 8.16 & 1.55 & 134 & -- \\
EkstraAktiviteler, $\beta_{12}$ & 4.30 & 5.59 & 0.77 & 134 & -- \\
\hline Rastgele Etkiler & Standart sapma & Varyans bileşenleri & s.d & $\chi^{2}$ & \\
\hline Düzey2 hata, $u_{0}$ & 47.95 & 2299.61 & 134 & 3170.36 & \\
Düzey1 hata, $r$ & 54.59 & 2980.25 & & & \\
\hline * $p<0.05$ & & & &
\end{tabular}

Tablo 3 incelendiğinde Terk değişkeni katsayısı $\left(\beta_{03}\right)$ yaklaşık 0.64 standart hata ile yaklaşık -1.32 olarak kestirildiği görülmüştür. Bu katsayının $p$ değeri istatistiksel olarak manidar bulunduğu $(p<0.05$, $s d=134)$ ve negatif bir değer aldığı için okullardaki öğrenci terklerinin artması ile öğrencilerin problem çözme yeterliği puanlarının düştüğü söylenebilir. Başka bir ifade ile okul terkinin fazla olduğu bir okula giden öğrencinin problem çözme yeterliği puanı, okul terkinin az olduğu bir okula giden öğrencinin problem çözme yeterliği puanından 1.32 birim daha düşüktür. Terk değişkeni katsayısının $\left(\beta_{03}\right) \% 95$ güven aralığı oluşturulduğunda, gerçek değerinin -0.07 ile -2.57 aralığında olması beklenir. Bu değişkenin gerçek hayatta ne kadar etkiye sahip olduğunu incelemek için etki büyüklüğü hesaplanmıştır. Terk değişkenin etki büyüklüğü göz önüne alındığında (-0.02) bu değişkenin etkisinin günlük hayatta hissedilmeyecek kadar az olduğu söylenebilir.

Ortalamaların bağımlı olduğu model analizi sonucunda istatistiksel olarak manidar etkiye sahip olan bir diğer değişken Ogrtmorali' $\operatorname{dir}(p<0.05, s d=134)$. Ogrtmorali değişkeninin katsayısı $\left(\beta_{07}\right)$ yaklaşık 4.65 standart hata ile yaklaşık 10.56 olarak kestirilmiştir. Bu doğrultuda öğretmen moralinin yüksek olduğu okula giden bir öğrencinin problem çözme yeterliği puanı, öğretmen moralinin düşük olduğu okula giden bir öğrenciden 10.56 birim daha fazladır yorumu yapılır. Ogrtmorali değişkeni katsayısının $\left(\beta_{03}\right) \% 95$ güven aralığı oluşturulduğunda, bu katsayının gerçek değerinin 1.45 ile 19.67 aralığında olması beklenir. $\mathrm{Bu}$ değişkenin gerçek hayatta etkisinin hissedilip hissedilmediğini incelemek için etki büyüklüğü hesaplanmıştır. Bu değer 0.18 olarak bulunmuştur. Bu değer öğretmen morallerinin yüksek olduğu okullarda öğrenim gören öğrencilerin problem çözme yeterliği puanları, öğretmen moralleri düşük olan okullarda öğrenim gören öğrencilere göre 0.18 standart sapma daha fazla olduğunu ifade etmektedir. Ogrtmorali değişkenin etki büyüklüğü göz önüne alındığında (0.18) bu değişkenin küçük bir etkiye sahip olduğu, başka bir ifade ile günlük hayatta etkisinin çok az hissedildiği söylenebilir.

Son olarak Matyarisi değişkeni katsayısının $\left(\beta_{09}\right)$ istatistiksel olarak manidar olduğu görülmektedir $(p<0.05, \mathrm{sd}=134)$. Matyarisi değişkeni katsayısı yaklaşık 14.21 standart hata ile yaklaşık -48.65 olarak kestirilmiştir ve bu katsayının gerçek değerinin -76.5 ile -20.8 aralığında olması beklenir. Bu durum matematik dersi için s1k s1k yarışma düzenlenen bir okula giden öğrencinin, matematik dersi için yarışma düzenlenmeyen bir okula giden öğrenciden 48.65 birim daha düşük problem çözme yeterliği puanına sahip olduğu şeklinde yorumlanır. Bu değişkenin etki büyüklüğü incelendiğinde, değişken etkisinin günlük hayatta hissedilebildiği söylenir. Aynı zamanda matematik dersi için yarışma 
düzenlenmeyen okullarda öğrenim gören öğrencilerin problem çözme yeterliği puanları, matematik dersi için yarışma düzenlenen okullarda öğrenim gören öğrencilere göre 0.84 standart sapma daha yüksektir yorumu yapılabilir.

Sırbistan'da PISA 2012 çalışmasına katılan okulların, problem çözme yeterliği puanları arasındaki farkı açıklayan okul düzeyi değişkenlerinin belirlenmesi için kurulmuş olan modelin analiz sonuçları Tablo 4'te verilmiştir. Tablo 4 incelendiğinde öğrencilerin problem çözme yeterliği puanlarına 2 değişken etkisinin (engel ve bağış) manidar $(p<0.05)$; 9 (toplam matematik öğretmeni sayısı, terk, uzmanlık, matematik öğretmeni oran1, öğretmen morali, eksiklik, matematik yarışı, sanat kulübü, aktiviteler ve ekstra aktiviteler) değişken etkisinin ise manidar olmadığg $(p>0.05)$ görülmektedir.

Tablo 4. Sırbistan için Ortalamaların Bağımlı Olduğu Model Analizi Sonucu

\begin{tabular}{llllll}
\hline Sabit etkiler & Katsayılar & Standart hata & $t$ & $\begin{array}{l}\text { Yaklaş1k } \\
\text { s.d }\end{array}$ & $\begin{array}{l}\text { Etki } \\
\text { Büyük. }\end{array}$ \\
\hline Kesim Noktas1, $\beta_{00}$ & 519.98 & 43.75 & 11.89 & 119 & \\
Engel, $\beta_{01}$ & $-14.15^{*}$ & 5.85 & -2.42 & 119 & -0.25 \\
Nmo, $\beta_{02}$ & 0.69 & 2.35 & 0.29 & 119 & --- \\
Terk, $\beta_{03}$ & -1.83 & 2.33 & -0.79 & 119 & --- \\
Bag1s, $\beta_{04}$ & $0.33 *$ & 0.13 & 2.51 & 119 & 0.006 \\
Uzmanlik, $\beta_{05}$ & 0.03 & 0.12 & 0.27 & 119 & --- \\
OranMo, $\beta_{06}$ & 326.37 & 189.37 & 1.72 & 119 & --- \\
OgrtMorali, $\beta_{07}$ & 3.47 & 6.31 & 0.55 & 119 & --- \\
Eksiklik, $\beta_{08}$ & -12.51 & 8.56 & -1.46 & 119 & --- \\
MatematikYarisi, $\beta_{09}$ & -13.29 & 9.98 & -1.33 & 119 & --- \\
SanatKulubu, $\beta_{10}$ & -12.79 & 12.55 & -1.02 & 119 & --- \\
Aktiviteler, $\beta_{11}$ & -19.97 & 11.20 & -1.78 & 119 & --- \\
EkstraAktiviteler, $\beta_{12}$ & 3.63 & 8.36 & 0.43 & 119 & --- \\
\hline Randum Etkiler & Standart sapma & Varyans & s.d & $\chi^{2}$ & \\
& & bileşenleri & & & \\
\hline Düzey2, $u 0$ & 49.58248 & 2458.42 & 119 & 1832.167 & \\
Düzey1, $r$ & 70.03086 & 4904.32 & & & \\
\hline$* p<0.05$ & & & &
\end{tabular}

Tablo 4 incelendiğinde Engel değişkeni katsayısı $\left(\beta_{01}\right)$ yaklaşık 5.85 standart hata ile yaklaşık -14.15 olarak kestirildiği görülmüştür. Bu katsayının $p$ değeri istatistiksel olarak manidar bulunduğu $(p<0.05$, $\mathrm{sd}=119)$ ve negatif bir değer aldığı için okullardaki öğrenmeyi engelleyici durumların artması ile öğrencilerin problem çözme yeterliği puanlarının düştüğü söylenebilir. Başka bir ifade ile öğrenmeyi engelleyici durumların fazla olduğu okuldaki bir öğrencinin problem çözme yeterliği puanı, öğrenmeyi engelleyici herhangi bir durumun olmadığı okuldaki öğrencinin problem çözme okuryazarlığ puanından 14.15 birim daha düşüktür. Engel değişkeni katsayısının $\left(\beta_{03}\right) \% 95$ güven aralığı oluşturulduğunda, gerçek değerinin -25.62 ile -2.68 aralığında olması beklenir. Engel değişkenin etki büyüklüğü hesaplandığında $(-0.25)$ bu değişkene ait etkinin günlük hayatta çok az hissedildiği söylenebilir. Çok fazla öğrenme engeline sahip okullardaki öğrencilerin, öğrenme engeli olmayan okullardaki öğrencilere göre problem çözme okuryazarlığı 0.25 standart sapma daha düşüktür.

Tablo 4 incelendiğinde Ailebagisi değişkeni katsayısının $\left(\beta_{04}\right)$ istatiksel olarak manidar kestirildiği görülmektedir $(p<0.05, \mathrm{sd}=119)$. Ailebagisi değişkeni katsayısı yaklaşık 0.13 standart hata ile yaklaşık 0.33 olarak kestirilmiştir ve bu katsayının gerçek değerinin 0.08 ile 0.58 aralığında olması beklenir. $\mathrm{Bu}$ katsayının istatistiksel olarak manidar bulunması aileler tarafindan desteklenen okullardaki öğrencilerin problem çözme yeterliğinin, aileler tarafından desteklenmeyen okullardaki öğrencilere göre 0.33 birim daha fazla olduğu seklinde yorumlanır. Etki büyüklüğü incelendiğinde, bu değişken etkisinin günlük hayatta hissedilemeyecek kadar küçük olduğu söylenebilir. 


\section{Araştırma Problemi ile İlgili Bulgular}

Türkiye ve Sırbistan'da etkisi manidar bulunan okul değişkenleri, PISA 2012 problem çözme yeterliğindeki varyansın ne kadarını açıkladığına dair sorunun cevaplanması için ortalamaların bağımlı olduğu model rastgele etkiler analiz sonucu Tablo 5 'te raporlanmıştır.

Tablo 5. Türkiye için Ortalamaların Bağımlı Olduğu Modeli Rastgele Etkiler Analizi Sonucu

\begin{tabular}{llllll}
\hline Ülkeler & Rastgele Etkiler & Standart sapma & Varyans bileşenleri & s.d & $\chi^{2}$ \\
\hline Türkiye & Düzey2 hata, $u$ o & $47.95^{*}$ & 2299.61 & 134 & 3170.36 \\
& Düzey1 hata, $r$ & 54.59 & 2980.25 & & \\
Sirbistan & Düzey2, u0 & $49.58248^{*}$ & 2458.42 & 119 & 1832.167 \\
& Düzey1, r & 70.03086 & 4904.32 & & \\
\hline
\end{tabular}

${ }^{* p}<0.05$

Tablo 5, ikinci düzeye okul değişkenleri eklendikten sonra okul düzeyindeki varyansın her iki ülke için ne olduğunu göstermektedir. Okul değişkenlerinin ikinci düzey varyansının ne kadarını açıkladıklarının belirlenmesi için Tablo 2'deki varyanstan Tablo 5'teki varyanslar çıkarılarak, Tablo 5 'teki varyansa bölünür. Türkiye için okul düzeyinde etkili değişkenlerin (Terk, Ogrtmorali ve Matyarisi), okul düzeyinde açıkladıkları varyans oran1 0.31 olarak hesaplanmıştır ((3335.68 2299.61)/3335.68). Okul düzeyinin problem çözme yeterliği puanlarındaki değişkenliğin 0.53'ünü açıkladığı göz önüne alınırsa Terk, Ogrtmorali ve Matyarisi değişkenlerinin problem çözme yeterliği puanlarındaki değişkenliğin $0.16^{\prime}$ sını açıkladığ 1 belirlenmiştir. Sırbistan için okul düzeyinde etkili değişkenlerin (Engel ve Ailebagisi), okul düzeyinde açıladıkları varyans oranı 0.21 olarak hesaplanmıştır ((3107.07-2458.42)/3107.07). Okul düzeyinin problem çözme yeterliği puanlarındaki değişkenliğin 0.39 'unu açıkladığı göz önüne alınırsa Engel ve Ailebagisi değişkenlerinin problem çözme yeterliği puanlarındaki değişkenliğin 0.08 ' ini açıkladığı belirlenmiştir.

Türkiye ve Surbistan'da PISA 2012 problem çözme yeterliğine etki eden okul değişkenlerinin benzerliklerini incelemek için HLM analizine her iki ülke için ortak 12 değişken dahil edilmiştir. Bu değişkenler: Engel, Matogrts, Terk, Ailebagi, Ogrtuzmanligi, Matogrtorani, Ogrtmorali, Ogrteksikligi, Matyarisi, Sanatklubu, Ulkeyeozguetkinlik ve Ekstraaktivite'dir. Her iki ülke için yapılan HLM analiz sonuçları Tablo 3 ve Tablo 4'te verilmiştir. İlgili tablolar incelendiğinde Türkiye örnekleminde Terk, Ogrtmorali ve Matyarisi değişkenlerinin Sırbistan örnekleminde ise Engel ve Ailebagi değişkenlerinin problem çözme yeterliği üzerindeki etkilerinin manidar olduğu görülmektedir. Sonuç olarak iki ülkede problem çözme yeterliğini yordayan ortak bir değişken olmadığı sonucuna ulaşılmıştır.

\section{TARTIŞMA ve SONUÇLAR}

Bu çalışma Türkiye ve Strbistan'ın PISA 2012 problem çözme yeterliğine etki eden okul değişkenlerinin belirlenmesi ve karşılaştırılması amacıyla yapılmıştır. Bu amaç doğrultusunda her iki ülkeden PISA 2012 uygulamasına katılmış okullardan elde edilen veriler üzerinde ayrı ayrı iki düzeyli HLM analizi yapılmıştır. HLM analizi üç düzeye de izin vermektedir. Eğer bu çalışma üç düzeyli HLM analizi ile yapılacak olsaydı üçüncü düzeyi ülkelere ait değişkenler oluşturacaktı. Fakat araştırmada ilgilenilen sadece iki ülke vardır ve HLM analizinin yansız kestirimde bulunması için son düzeydeki birim sayısının 30 ve üzeri olması gerekir (Maas ve Hox, 2005). Bu nedenle bu araştırma iki düzeyli HLM analizi ile sınırlıdır.

Problem çözme yeterliğine etki eden değişkenleri belirlemek için PISA 2012 okul anketinden yararlanılmıştır. Araştırmanın başında okul anketinde bulunan tüm değişkenler HLM analizine alınmak istenmiştir. Fakat yapılan ön analizler sonucunda Türkiye için 47 değişken, Sırbistan için 21 değişkenin HLM analizine alınabileceği görülmüştür. Her iki ülkede problem çözme yeterliğine etki eden okul değişkenleri belirlenip karşılaştırılmak istendiği için her iki ülkede ortak olan değişkenler 
HLM analizine dahil edilmiştir. $\mathrm{Bu}$ doğrultuda bu araştırmada sadece 12 değişkenin etkisi incelenebilmiştir ve bu sınırlılıkla bulgular tartışılmıştır.

12 değişken ile sınırlı olan bu çalışmada öncelikle HLM analizinin avantajından faydalanılarak düzeylerin problem çözme yeterliği puanlarındaki varyansı açıklama oranları incelenmiştir. Öğrenci başarısındaki varyansın büyük bir kısmının öğrenci düzeyi tarafından açıklanması beklenir (Scheerens ve Bosker, 1997; Teodorovic, 2005). Nitekim Ryoo'nun 2001 yılında HLM analizi ile yaptığı uluslararası karşılaştırma çalışmasında başarıdaki varyansın büyük çoğunluğunun öğrenci düzeyi tarafindan, kalan kısmının okul düzeyi tarafından açıklanması bu durumu desteklemektedir. Benzer şekilde Scheerens ve Bosker'ın (1997) çalışmaları da bu durumu desteklemektedir. Fakat varyansın düzeyler tarafından açıklanma oranı her zaman bu şekilde olmamaktadır. Mohammadpour ve Abdul Ghafar'ın (2014) yaptığı uluslararası karşılaştırma çalışması ise bu duruma örnek verilebilir. Mohammadpour ve Abdul Ghafar (2014) başarıdaki varyansın küçük bir kısmının öğrenci düzeyi tarafından, kalan kısmının ise okul düzeyi tarafından açıklandığını belirlemişlerdir. Bu çalışmada problem çözme yeterliği puanlarındaki varyansın büyük bir kısmı Türkiye'de okul düzeyi tarafından açılanırken, Sırbistan'da öğrenci düzeyi tarafindan açıklanmaktadır. Bu doğrultuda Türkiye'deki okulların, öğrenci başarıları üzerinde daha fazla etkiye sahip olduğu söylenebilir.

Türkiye ve Sırbistan'da problem çözme yeterliğini etkileyen okul değişkenlerinin incelendiği bu çalışmada Satıcı'nın (2008) çalışmasına benzer şekilde ülkelerde farklı değişkenlerin başarıyı etkilediği görülmüştür. Sırbistan için "Engel ve Bagıs" değişken etkileri, Türkiye için "Terk, OgrtMorali ve MatematikYarisi" değişken etkileri istatistiksel olarak manidar bulunmuştur. Sirbistan'daki hemen hemen her okulun 1sitmas1, aydınlatmas1, masas1, sandalyesi, tahtas1 endüstrileşmiş ülkelere benzemektedir. $\mathrm{Bu}$ nedenle temel okul tesisleri ve teknolojik araç-gereç imkanlarının öğrenci öğrenmelerindeki farklılıklar üzerinde düşük etkilerinin olması beklenilen bir durumdur (Teodorovic, 2005). Ayrıca öğrenci gelişimlerini değerlendirme sıklığı, velilere ulaşılabilirlik ve aile katılım politikası daha çok sınıf düzeyinde incelenen ve etkileri düşük olan değişkenlerdir (Kavgacı, 2010; Teodorovic, 2005). PISA uygulaması gereği her okuldan bir sınıf uygulamaya katıldığı için bu çalışmada sınıf düzeyi okul düzeyi ile birleştirilmiştir ve Teodorovic'in (2005) belirttiği üzere "Bagıs" değişkeninin etkisinin düşük olduğu tespit edilmiştir. Benzer şekilde “Terk” değişkeni de Türk öğrencilerinin başarılarını çok düşük düzeyde etkileyen bir değişkendir. Öğrenim gördüğ̈̈ okuldan, yöneticilerden ve öğretmenlerden memnun olmayan, gerekli yardımı alamayan, kuralsız davranışların çok olduğu bir okulda öğrenciler, okulu bırakma eğilimindedirler (Şimşek ve Şahin, 2012). Böyle bir ortamda verilen eğitimin kalitesi tartışılır ve öğrenci başarısının düşük olması beklenir. Ayrıca öğrencinin başarısının yanında öğretmenlerin motivasyonu, morali ve okula duydukları güven de düssecektir. Çalıştığı ortamda güvenli hissetmeyen öğretmenlerin işlerinde verimli olması beklenemez. Nitekim Mihyap (2011) yapmış olduğu çalışmasında çalışma koşullarının uygun, güvenli bir okul ortamında çalıştı̆̆ını düşünen öğretmenlerin öğrencilerinin daha başarılı olduğunu tespit etmiştir.

Literatürde okulların öğrenci başarıları üzerindeki etkilerini araştıran birçok çalışma (Çalık ve Kurt, 2010; Kavgac1, 2010; Mihyap, 2011, vb.) mevcuttur. Bu çalışmalar incelendiğinde etkisi incelenen değişkenleri okul iklimi kavramı altında toplamak mümkündür. Okul iklimi kavramı pek çok farklı şekilde tanımlansa da genel olarak öğrencilerin, öğretmenlerin, yöneticilerin ve velilerin etkilediği ve etkilendiği örgütsel bir özellik olduğu söylenebilir (Çalık ve Kurt, 2010). Bu bağlamda bir okulun eğitimi etkileyen fiziki koşulları, aile-okul ilişkisi, öğretmenlerin ve öğrencilerin okula ilişkin algıları okul iklimi çalışmalarında incelenmektedir. Bu çalışma sonucunda etkisi manidar bulunan değişkenlerin PISA okul anketinde ilgili oldukları kategoriler incelendiğinde "MatematikYarisi" değişkeni dışındaki tüm değişkenlerin "okul iklimi" kategorisinin bileşenleri olduğu görülmüştür. Matematik yarışı değişkeni ise okulun eğitimi, müfredatı ve değerlendirmesi kategorisine aittir.

HLM analizi sonucu iki ülkede farklı değişkenlerin problem çözme yeterliği üzerinde manidar etkileri olduğu görülse de bu değişkenlerin okul iklimi kavramının birer bileşeni olması oldukça dikkate değerdir. Mortimore, Sammons, Stoll, Lewis ve Ecob'un 1988 yılında yaptıkları çalışmada "okul iklimi" en önemli okul düzeyi değişkenlerinden biri olarak belirlenmiştir. 2000'li yıllara gelindiğinde Scheerens (2000) kitabında, okul iklimi gibi değişkenlerin başarıya etkilerini inceleyen çalışmalar 
üzerindeki meta-analiz çalışmalarını özetlemiştir. Scheerens (2000) incelemesi sonucunda okul iklimi gibi değişkenlerin az da olsa öğrenci başarısını etkiledikleri sonucuna ulaşmıştır. 2001 yılında ise OECD'nin PISA verilerini kullanarak yaptığ çalışmanın sonucunda benzer şekilde okul anatomisi, ögretmen morali gibi okul iklimi değişkenlerinin öğrencilerin başarılarını etkilediği tespit edilmiştir. Sonuç olarak Mihyap'ın (2011) çalışmasında belirttiği gibi uygun okul iklimi ve çalışma koşullarına sahip okullara giden öğrencilerin başarıları diğer öğrencilere göre anlamlı derecede yüksektir.

HLM analizi sonucunda yukarıda bahsedildiği gibi Sırbistan için "engel ve bağış" değişken etkileri, Türkiye için "terk, öğretmen morali ve matematik yarışs" değişkenlerinin problem çözme yeterliği üzerinde istatistiksel olarak anlamlı etkisi olduğu görülmüştür. Etki büyüklükleri dikkate alındığında ise Sırbistan'da "engel" değişkeninin, Türkiye'de "öğretmen morali ve matematik yarışı" değişkenlerinin problem çözme yeterliği üzerindeki etkilerinin istatistiksel olarak anlamlı olmasının yanı sıra pratikte de önemli oldukları belirlenmiştir. Okul değişkenlerinin problem çözme yeterliği puanlarındaki varyansı açıklama yüzdeleri incelendiğinde Sırbistan için 0.08 , Türkiye için 0.16 olduğu görülmüştür. OECD'nin (2001) yaptığ 1 çalışmada bu oran 5.8 olarak hesaplanmıştır. Ancak OECD (2001)'in çalışmasında bu çalışmaya kıyasla okul düzeyinde daha fazla değişken olduğu için başarıdaki varyansın daha fazla açıklanması beklenilen bir durumdur. Teodorovic $(2005$, s. 74$)$ çalışmasında okul düzeyinde bulunan okul kültürü ve okul iklimi değişkenlerinin Sırp öğrencileri üzerinde küçük etkiye sahip olduklarını ifade ettikten sonra bunun nedenlerini sıralamıştır. Bu nedenlerden birincisi, Farrell ve Oliveira (1993) ve Scheerens'in (2000) çalışmalarında belirttiği üzere endüstriyel ülkelerde etkili okul değişkenlerinin küçük etki büyüklüklerine sahip olmalarıdır. Sırbistan'da okul büyüklügü̈, öğrencilerin teknolojik araç-gereçlere ulaşma imkanı gibi konularda endüstriyel ülkelere benzediği için bu değişkenlerin başarıda açıkladıkları varyans düşüktür. İkinci olarak da Sırp öğrenciler vakitlerini daha çok sınıfta geçirdikleri için okul özelliklerinden pek etkilenmiyor olmalarıdır.

\section{ÖNERILER}

Türkiye ve Sirbistan örnekleminde PISA 2012 problem çözme yeterliğini etkileyen okul değişkenlerinin belirlenmesi ve karşılaştırılması amaçlanan bu çalışmada Türkiye'de okul düzeyinin ögrenci başarısında Sırbistan'a göre daha etkili olduğu belirlenmiştir. Bu durum Türkiye'de yetkililerin doğru kararlar alarak okullarda yapacakları değişikliklerle öğrenci başarılarını daha hızlı arttırabileceklerini göstermektedir. Örneğin bu çalışmada öğretmen morali öğrenci başarısını etkileyen diğer bir değişken olarak tespit edilmiştir. Öğrencilerin okulda bulundukları sürede öğretmenlerle olan ilişkileri onların ders başarısını etkilemektedir. Yetkililer, yapacakları iyileştirmeler ve alacakları önlemlerle birlikte öğretmen morallerini yükselterek öğrenci başarılarını arttırabilirler. Ayrıca okullarda yapılan denemelerle öğrenciler sıralanarak karşılaştırmalar yapılmaktadır. Kendini bir yarışın içinde hisseden öğrenci başarısız olmaktadır. Öğrenciler bir yarışın içine sürüklenmeden, bireysel olarak değerlendirilerek başarılarının artması sağlanabilir. Sırbistan'da okul engelinin öğrenci başarısını olumsuz engellediği belirlenmiştir. Sırp yetkililerin okul kaynaklarında yapacakları iyileştirmeler ile öğrenci öğrenmeleri arttırılabilir ve dolayısıyla öğrenci başarıları arttırılabilir.

Bu çalışmada her iki ülke için ortak olan 12 değişkenin etkisi incelenmiştir. Başka bir çalışmada her iki ülke için problem çözme yeterliği ile ilişkili diğer değişkenler analize dahil edilerek ülkeler bireysel değerlendirilebilir. HLM analizi sonucunda Surbistan için "engel ve bağış" değişken etkileri, Türkiye için "terk, öğretmen morali ve matematik yarışı" değişken etkileri istatistiksel olarak anlamlı bulunmuştur. $\mathrm{Bu}$ değişkenler için yürütülecek nitel çalışmalar ile değişken etkileri daha detaylı incelenebilir. Bu çalışmada iki düzeyli HLM analizi kullanılmıştır. Çalışmaya başka ülkeler dahil edilerek üç düzeyli HLM analizi ile çalışma tekrarlanabilir. Bu çalışmadaki değişkenler çok düzeyli yapısal eşitlik modeli ile tekrar incelenebilir. 


\section{KAYNAKÇA}

Aydın A., Sarıer Y. ve Uysal Ş. (2012). Sosyoekonomik ve sosyokültürel değişkenler açısından PISA matematik sonuçlarının karşılaştırılması. Eğitim ve Bilim, 37(164), 20-30.

Baucal, A., Pavlovic-Babic, D., \& Willms, J. D. (2007). Differential selection into secondary schools in Serbia. Prospects, 37(4), 539-546.

Baucal, A., \& Pavlovic-Babic, D. (2009). Quality and equity of education in Serbia: Educational opportunities of the vulnerable PISA assessment 2003 and 2006 data. Ministry of Education of the Republic of Serbia.

Bryk, A., \& Raudenbush, S. (1988). Toward a more appropriate conceptualization of research on school effects: A three-level hierarchical linear model. American Journal of Education, 97(1), 65-108.

Büyüköztürk, Ş., Çakmak, E. K., Akgün, Ö. E., Karadeniz, Ş. ve Demirel, F. (2008). Bilimsel araştırma yöntemleri (14. bask1). Ankara: Pegem Akademi.

Cadiz, J. (2001). Differences in 4th grade mathematics achievement among chilean elementary schools an application of hierarchical linear models (HLMS) (Doctoral Dissertation). Available from ProOuest Dissertations and Theses database.

Çalık, T. ve Kurt, T. (2010). Okul iklimi ölçeği’nin (OİÖ) geliştirilmesi. Eğitim ve Bilim Dergisi, 35(157), 167180.

Çelen F. K., Çelik A. ve Seferoğlu S. S. (2011, Şubat). Türk eğitim sistemi ve PISA sonuçları. Akademik Bilişim'11-XIII. Akademik Bilişim Konferansı, İnönü Üniversitesi, Malatya.

Demir, E. (2010). Uluslararası ögrenci değerlendirme programı (PISA) bilişsel alan testlerinde yer alan soru tiplerine göre Türkiye'de ögrenci başarlları (Yüksek lisans tezi, Hacettepe Üniversitesi, Ankara.) https://tez.yok.gov.tr/UlusalTezMerkezi/tezSorguSonucYeni.jsp adresinden edinilmiştir.

EARGED. (2005). OECD PISA 2003 araştırmasının Türkiye ile ilgili sonuçları-PISA 2003 projesi ulusal nihai rapor. $\quad$ http://pisa.meb.gov.tr/wp-content/uploads/2013/07/PISA-2003-Ulusal-Nihai-Rapor.pdf adresinden erişildi.

Farrell, J. P., \& Oliveira, J. B. (1993). Teachers in developing countries: Improving effectiveness and managing costs. Washington, DC: The World Bank.

Fuller, B., \& Clarke, P. (1994). Raising school effects while ignoring culture? Local conditions and the influence of classroom tools, rules, and pedagogy. Review of Educational Research, 64(1), 119-157.

Hox, J. J. (2010), Multilevel analysis: Techniques and applications. (2nd ed.) Great Britain: Routledge.

İş, Ç. (2003). Uluslararası öğrenci başarı belirleme programına göre (PISA) matematik okur yazarlı̆̆ını belirleyen faktörlerin kültürler arası karşılaştırılması (Yüksek lisans tezi, Ortadoğu Teknik Üniversitesi, Ankara). https://tez.yok.gov.tr/UlusalTezMerkezi/tezSorguSonucYeni.jsp adresinden edinilmiştir.

Kavgac1, H. (2010). İlkögretimde örgütsel iklim ve okul-aile ilişkileri (Yüksek lisans tezi, Gazi Üniversitesi, Ankara). https://tez.yok.gov.tr/UlusalTezMerkezi/tezSorguSonucYeni.jsp adresinden edinilmiştir.

Kılıç, S., Çene, E. ve Demir, İ. (2012). Comparison of learning strategies for mathematics achievement in Turkey with eight countries. Educational Sciences: Theory and Practice, 12(4), 2594-2598.

Lesh, R., \& Zawojewski, J. S. (2007). Problem solving and modeling. In F. Lester (Ed.), The handbook of research on mathematics teaching and learning (2nd ed., pp. 763-804). Reston, VA: National Council of Teachers of Mathematics; Charlotte, NC: Information Age Publishing (joint publication).

Maas, C. J. M., \& Hox, J. J. (2005). Sufficient sample sizes for multilevel modeling. Methodology, 1(3), 86-92.

Mihyap, K. (2011). Uluslararası matematik ve fen eğilimleri araştırması (2007) tarafindan belirlenen ögretmen endekslerinin incelenmesi ve bu değişenlerin sekizinci sınıf Türk öğrencilerinin başarısı ile ilişkisinin analizi (Yüksek lisans tezi, Ortadoğu Teknik Üniversitesi, Ankara). https://tez.yok.gov.tr/UlusalTezMerkezi/tezSorguSonucYeni.jsp adresinden edinilmiştir.

Milli Eğitim Bakanlığı (2015). PISA 2012 araştırması ulusal nihai rapor. https://drive.google.com/file/d/0B2wxMX5xMcnhaGtnV2x6YWsyY2c/view adresinden erişildi.

Mohammadpour, E., \& Abdul Ghafar, M. N. (2014). Mathematics achievement as a function of within-and between-school differences. Scandinavian Journal of Educational Research, 58(2), 189-221.

Mortimore, P., Sammons, P., Stoll, L., Lewis, D., \& Ecob, R. (1988). School matters: The junior years. England: Somerset. Retrieved from https://books.google.com.tr/books

OECD. (2001). Knowledge and skills for life: First results from PISA 2000. Paris, France: OECD. Retrieved from https://www.oecd.org/edu/school/programmeforinternationalstudentassessmentpisa/33691620.pd $\underline{\mathrm{f}}$

OECD. (2004a). Learning for tomorrow's world: Firsts results from PISA 2003. Paris, France: OECD. Retrieved from http://www.oecd.org/education/school/programmeforinternationalstudentassessmentpisa/34002 216.pdf

OECD. (2004b). Problem solving for tomorrow's world first measures of cross-curricular competencies from PISA 2003. Paris, France: OECD. Retrieved from https://www.oecd.org/edu/school/programmeforinternationalstudentassessmentpisa/34009000.pdf 
OECD. (2005). PISA 2003 technical report. Paris, France: OECD. Retrieved from https://www.oecd.org/edu/school/programmeforinternationalstudentassessmentpisa/35188570.pdf

OECD. (2009). PISA 2009 assessment framework: Key competencies in reading, mathematics and science. Paris, France: OECD. Retrieved from https://www.oecd.org/pisa/pisaproducts/44455820.pdf

OECD. (2013a). PISA 2012 assessment and analytical framework: Mathematics, reading, science, problem solving and financial literacy. Paris, France: OECD. Retrieved from http://dx.doi.org/10.1787/9789264190511-en

OECD. (2013b). PISA result from PISA 2012 problem solving. Paris, France: OECD. Retrieved from https://www.oecd.org/pisa/.../PISA-2012-results-turkey.pdf

OECD. (2014). PISA 2012 technical report. Paris, France: OECD. Retrieved from https://www.oecd.org/pisa/pisaproducts/PISA-2012-technical-report-final.pdf

Raudenbush, S. W. and Bryk, A. S. (2002). Hierarchical linear models (2nd ed.). Newbury Park, CA: Sage.

Ryoo, H. (2001). Multilevel influences on student achievement: An international comparative study (Doctoral Dissertation). Available from ProOuest Dissertations and Theses database.

Satıcı, K. (2008). PISA 2003 sonuçlarına göre matematik okuryazarlı̆̆ını belirleyen faktörler: Türkiye ve Hong Kong-Çin (Yüksek lisans tezi, Balıkesir Üniversitesi, Balıkesir). https://tez.yok.gov.tr/UlusalTezMerkezi/tezSorguSonucYeni.jsp adresinden edinilmiştir.

Scheerens, J. (2000). Improving school effectiveness (Fundamentals of Educational Planning No.68). http://doc.utwente.nl/92592/1/Improving-122424e.pdf adresinden erişildi.

Scheerens, J., \& Bosker, R. J. (1997). The foundations of educational effectiveness. Oxford, England: Pergamon.

Schleicher, A. (2007). Can competencies assessed by PISA be considered the fundamental school knowledge 15 year olds should possess? Journal of Educational Change, 8, 349-357. doi:10.1007/s10833-007-9042-x

Şimşek, H. ve Şahin, S. (2012). İlköğretim ikinci kademe öğrencilerinde okulu bırakma eğilimi ve nedenleri (Şanlıurfa ili örneği). Abant İzzet Baysal Üniversitesi Ĕgitim Fakültesi Dergisi, 12(2), 41-72.

Teodorovic, J. (2005). Factors related to student achievemenet: What works for children in Serbia? (Doctoral Dissertation). Available from ProOuest Dissertations and Theses database.

Yavuz, E., \& Atar, H. Y. (2016). Examining the effects of students and school variables on PISA 2012 problem solving achievement in Turkey. New Trends and Issues Proceedings on Humanities and Social Sciences, 2(5), 24-30. Retrieved from http://sproc.org/ojs/index.php/pntsbs/article/view/1124.

\section{EXTENDED ABSTRACT}

\section{Introduction}

The weights given to the areas that are measured in different years in PISA vary. In other words, the selected area is examined in more detail. Problem-solving competency was given in 2003 and 2012. In 2003 and 2012 the average of? problem solving competency of Turkey was approximately 408 and 454; and the average of problem solving competency of Serbia is approximately 420 and 473, respectively (OECD, 2005, 2014). According to the OECD's PISA 2012 Turkey problem-solving report, Turkey and Serbia were at the same mathematical literacy level. But Serbia's problem-solving competency was higher than Turkey's. In this study, school variables that affect problem-solving competency of these two countries were examined and compared.

\section{Method}

In this study, causal comparison design was used in the quantitative research methods since it is aimed to determine and compare the variables that affect the problem solving competency of Turkey and Serbia in 2012 PISA exam. HLM analysis was performed on the data of 4494 students sampled from 147 schools in Turkey and 4059 students sampled from 132 schools in Serbia separately. All variables in the study were derived from the OECD school survey in order to obtain data related to the schools of pupils participating in PISA applications.

It was not possible to incorporate the school data of the two countries directly into the HLM analysis. For this reason, the school variables of the two countries have been examined in different contexts such as multiple connections, missing data, outliers, and they have been taken from the data when it 
is necessary. As a result of primarily analysis, there were twelve variables which were the same for two countries in the HLM analysis.

\section{Results and Discussion}

At the beginning of the study, all variables in the school survey were aimed to be included in the HLM analysis. However, as a result of the preliminary analysis, 47 variables for Turkey and 21 variables for Serbia could be taken into HLM analysis. The common variables for both countries were included in the HLM analysis, because school variables that affect problem-solving competency in both countries would be identified and compared. In this respect, only the effects of 12 variables were investigated in this study and the findings were discussed with this limitation.

In this study, which was limited to 12 variables, the explanatory ratios of the variance of problem solving competency of the levels were examined by taking advantage of the HLM analysis. It was expected that a large part of student variance would be explained by student level (Scheerens and Bosker, 1997; Teodorovic, 2005). However, the rate of disclosure by the levels of variance is not always that way, which can be exemplified by an international comparative study by Mohammadpour and Abdul Ghafar (2014). In this study, a large part of the variance in problem solving competency scores was explained by the school level in Turkey, whereas it was explained by the student level in Serbia. In this respect, it can be said that the schools in Turkey had more influence on student achievement.

As a result of HLM analysis, "obstacle and family donation" variable for Serbia and "abandon, teacher morale and mathematics competition" variable for Turkey were statistically significant. Almost every school in Serbia has a warming, lighting, table, chairs and board, which is similar to industrialized countries. For this reason, it was expected that basic school facilities and technological equipment facilities would have a low impact on the differences in student learning (Teodorovic, 2005). The frequency of evaluating student development, accessibility to parents, and family participation policy are variables that were examined at the class level and had little effect (Kavgac1, 2010; Teodorovic, 2005). This study was combined the class level and school level because PISA practice participated in a classroom practice from each school and it was determined that the effect of the "Fundraising" variable was low as indicated by Teodorovic (2005). Similarly, the "abandon" variant was found to be a variable that affects the success of Turkish students at a very low level. According to Şimşek ve Şahin (2012) students tend to leave the school at a school where there is a lot of unqualified behavior. Also they tend to leave when they are not satisfied with the school, the administrators and the teachers. The quality of education given in such an environment was discussed and the student's success was expected to be low. In such an environment, as well as the success of the student, the motivation, morale and confidence of the teacher would decrease. Teachers who do not feel safe in the working environment cannot be expected to be productive in their work. As a matter of fact, Mihyap (2011) found that the students who thought that their working conditions were in a safe and secure school environment were more successful.

In this study of school variables affecting problem-solving competency in Turkey and Serbia, it was seen that different variables in the countries affected problem solving success of students in the same way as in the study of Satıc (2008). When we examined the categories in which the variables with influence were relevant in the PISA school survey, it was seen that all variables except "math competition" were the components of the "school climate" category. Mathematics competition variable belongs to school education, curriculum and evaluation category. This finding is the result of the study of the OECD in 2001 that used PISA data. It has been determined that school climate variables such as school anatomy and teacher morale affect the success of the students. As a result, as stated in the study of Mihyap (2011), the success of students who go to schools with appropriate school climate and working conditions is significantly higher than the other students. Although it was found that for each countries different variables influence the problem-solving competency, it was quite remarkable that these variables are in common in that they are components of the school climate concept. 